\title{
Originals
}

\section{Prevention and suppression of autoimmune pancreatic Beta-cell destruction in BB rats by syngeneic lymphocytes obtained from long-term normoglycaemic donors}

\author{
B. Kuttler ${ }^{1}$, A. Dunger ${ }^{1}$, H.D. Volk ${ }^{2}$,T.Diamantstein ${ }^{3}$ and H.J.Hahn ${ }^{1}$ \\ ${ }^{1}$ Institute of Diabetes "G. Katsch", Karlsburg, ${ }^{2}$ Institute of Medical Immunology, Charite, Humboldt-University, and \\ ${ }^{3}$ Institute of Immunology, Klinikum Steglitz, Free University, Berlin, FRG
}

Summary. To prove whether a cell-mediated mechanism is responsible for maintaining long-term normoglycaemia in $\mathrm{BB} / \mathrm{OK}$ rats with a proved immune attack (insulitis, reduced Beta-cell volume), we transferred lymphocytes obtained from those rats into normoglycaemic diabetes-prone $\mathrm{BB} / \mathrm{OK}$ rats or into diabetic $\mathrm{BB} / \mathrm{OK}$ rats receiving a simultaneous syngeneic islet graft. Our results show the presence of a lymphocyte population in the long-term normoglycaemic $\mathrm{BB} / \mathrm{OK}$ rats, which is able to arrest pancreatic Beta-cell destruction in diabetes-prone $\mathrm{BB} / \mathrm{OK}$ rats detected by a decreased diabetes incidence following single lymphocyte transfusion. Syngeneic islets were destroyed by recurrence of the autoimmune process when transplanted into diabetic $\mathrm{BB} / \mathrm{OK}$ rats. Lymphocytes obtained from long-term nor- moglycaemic $\mathrm{BB} / \mathrm{OK}$ rats were able to protect the syngeneic $\mathrm{BB} / \mathrm{OK}$ islet graft from autoimmune destruction in diabetic $\mathrm{BB} / \mathrm{OK}$ rats, whereas allogeneic islet destruction was not prevented. The phenotype of the effective lymphocyte population is not yet clear, but it is negative for RT6. We conclude that the mechanism responsible for maintaining normoglycaemia in long-term normoglycaemic $\mathrm{BB} / \mathrm{OK}$ rats is cell mediated, because this property can be transferred to prevent autoimmune destruction of pancreatic Beta cells.

Key words: Islet transplantation, BB rat, autoimmune pancreatic Beta-cell destruction, lymphocyte transfer.
In an identical environment, only 30 to $60 \%$ of $\mathrm{BB}$ rats develop an insulin-dependent diabetes which is characterized by severe inflammation of pancreatic islets and a marked destruction of pancreatic Beta cells [1]. Despite an identical genetic background a portion of the animals did not develop hyperglycaemia, even when the rats were followed-up for more than 200 days. Recently, we observed insulitis in all the $\mathrm{BB} / \mathrm{OK}$ rats investigated independently, whether they developed hyperglycaemia or not [2]. This means that inflammation of islets does not necessarily lead to overt diabetes, suggesting that the BB/OK rats which did not develop diabetes (later referred to as long-term normoglycaemic BB rats) had arrested the immune destruction of pancreatic Beta cells spontaneously. Assuming that cell-mediated mechanisms were involved in such cessation processes, we isolated lymphocytes from these $\mathrm{BB}$ rats and transfused them into diabetes-prone $\mathrm{BB}$ rats or into diabetic $\mathrm{BB}$ rats receiving a simultaneous syngeneic islet graft, which is normally destroyed by recurrence of the autoimmune process [3-6].

\section{Materials and methods}

\section{Animals}

We divided 40 normoglycaemia diabetes-prone $\mathrm{BB} / \mathrm{OK}$ rats (plasma glucose: $6.9 \pm 0.2 \mathrm{mmol} / \mathrm{l}$ ) at an age of $92 \pm 1$ days into two groups and included them in the lymphocyte transfusion study. Spontaneously diabetic BB/OK rats ( $n=44,24$ male, 20 female) with a diabetes duration of $>3$ weeks (repeated plasma glucose $>20 \mathrm{mmol} / \mathrm{l}$, pancreatic insulin content $<1.0 \mathrm{pmol} / \mathrm{mg}$ wet/weight) served as recipients for the islet grafts. They were treated by a once daily injection of a long-acting insulin (heat-treatedBerl-Insulin, VEB Berlin Chemie, Berlin, Germany) to prevent loss of body weight. Neonatal (8-12 days of age) BB/OK rats and neonatal LEW.1A rats were used for preparation of donor islets. Normoglycaemic BB/OK rats (plasma glucose: $6.4 \pm 0.1 \mathrm{mmol} / \mathrm{l}$ ) with an age of $232 \pm 2$ days were used as lymphocyte donors $(n=98,55$ male, 43 female). All animals were kept under semi-barrier conditions [7] and had free access to food (sterilized rat pellet chow R13, VEB Futtermittelwerke Altglienicke, FRG and vitamins) and sterilized water.

\section{Lymphocyte preparation}

Lymphocytes were prepared from cervical lymph nodes, the spleen or peripheral blood as described earlier [8]. 
The number of cells for lymphocyte transfer was adjusted to 1.6 $2.5 \times 10^{7}$ per $2 \mathrm{ml}$ RPMI 1640 containing $1 \%$ neonatal calf serum. Viability was $>98 \%$ as ascertained by trypan blue exclusion.

\section{Islet isolation and graft characterization}

Donor pancreatic islets were prepared by fractionated collagenase digestion. The isolated islets were separated by centrifugation on a Dextran gradient [9] and hand-picked. For graft characterization islet insulin content [10] was determined.

\section{Lymphocyte transfusion into normoglycaemic diabetes-prone $B B / O K$ rats}

A mixture of splenocytes and cervical lymph node lymphocytes $\left(2.47 \pm 0.44 \times 10^{7}\right)$ was transfused into the inferior vena cava of 19 diabetes-prone $\mathrm{BB}$ rats ( 9 male, 10 female). Sham-transferred $\mathrm{BB}$ rats ( $n=21,11$ male, 10 female) served as controls (infusion of 2 ml RPMI 1640). Plasma glucose (Glucose Analyzer, Beckman Instruments, Fullerton, Calif., USA), was monitored once a week up to more than 200 days (meaning 120 days after transfusion). Overt diabetes was diagnosed by a plasma glucose above $10 \mathrm{mmol} / \mathrm{l}$ on two consecutive days.

\section{Lymphocyte transfusion and islet transplantation into diabetic $B B / O K$ rats}

Two thousand hand-picked islets were grafted under the kidney capsules of diabetic $\mathrm{BB} / \mathrm{OK}$ recipients. These were either untreated (control, syngeneic and allogeneic islet graft), transfused with a mixture of splenocytes and cervical lymph node lymphocytes (syngeneic and allogeneic islet graft; $2.45 \pm 0.22 \times 10^{7}$ cells and $2.01 \pm 0.05 \times 10^{7}$ cells) or peripheral blood lymphocytes (syngeneic islet graft; $1.66 \pm 0.08 \times 10^{7}$ ). At the time of transplantation the recipients were surgically biopsied to obtain pancreatic tissue which was used to measure the pancreatic insulin content [11]. Plasma glucose was monitored three times a week up to day 21 and then once a week up to day 120 . Islet destruction was considered as being the first of two consecutive days when plasma glucose exceeded $10.0 \mathrm{mmol} / \mathrm{l}$. Hyperglycaemic animals were killed, and the pancreas was taken for insulin extraction [11]. In normoglycaemic animals, the grafts were removed after 120 days for insulin extraction [11]. Plasma glucose of the nephrectomized rats was followed-up for further three consecutive days.

\section{Statistical analysis}

The results are given in mean values \pm SEM and a Student's $t$-test was used to check statistical significance.

\section{Results}

As Table 1 shows, the diabetes incidence of sham-transferred animals was $33 \%$. Lymphocyte transfusion decreased diabetes manifestation to $10 \%$ ( 2 of 19 ) of the

Table 1. Influence of lymphocyte transfer on diabetes incidence in diabetes-prone $\mathrm{BB} / \mathrm{OK}$ rats

\begin{tabular}{llll}
\hline Parameter & Dimension & $\begin{array}{l}\text { Sham-transferred } \\
\mathrm{BB} / \text { OK rats }\end{array}$ & $\begin{array}{l}\text { Adoptively-trans- } \\
\text { ferred BB/OK rats }\end{array}$ \\
\hline Diabetes & $\%$ & 33.3 & 10.5 \\
Incidence & & $(7 / 21)$ & $(2 / 19)$ \\
Sex & & 4 male; 3 female & 2 female \\
Age at onset & Days & $109 \pm 3$ & $152 \pm 41$ \\
\hline
\end{tabular}

treated $\mathrm{BB} / \mathrm{OK}$ rats and modified the time of manifestation in one of the two diabetic animals.

The islet insulin content of the 2000 grafted islets did not differ significantly between the several groups investigated and remained between $9020 \pm 1280 \mathrm{pmol}$ and $11500 \pm 440 \mathrm{pmol}$.

Following transplantation of the $\mathrm{BB} / \mathrm{OK}$ rat islets into untreated diabetic $\mathrm{BB} / \mathrm{OK}$ rats, we observed a graft destruction in 10 of 12 recipients (mean survival time $>28.5 \pm 12.5$ days) by the recurrence of hyperglycaemia within 20 days (Fig. 1 A). When the transplantation was combined with an additional transfusion of lymph node and spleen cells prepared from long-term normoglycaemic $\mathrm{BB} / \mathrm{OK}$ rats, normoglycaemia was reached within 4 weeks in 9 of 10 animals (Fig. 1B) and was maintained for at least 120 days (mean survival time $>97.1 \pm 12.0$ days). As Figure $1 \mathrm{C}$ demonstrates, peripheral blood lymphocytes also prevented graft destruction in five of six islet grafted $\mathrm{BB} / \mathrm{OK}$ rats for 120 days (mean survival time $101.0 \pm 19.0$ days). The graft removal caused an immediated increase in plasma glucose, indicating that the maintaine normoglycaemia was the result of a viable islet graft (Figs.1B, 1C). The graft insulin content at day 120 amounted to $17116 \pm 2101 \mathrm{pmol}$ in the BB/OK rats which were transfused with lymph node and spleen cells. The pancreatic insulin content remained low in each situation investigated.

The lymphocyte number transferred into the diabetic recipients of the two islet grafted groups (see Materials and methods) was significantly different $(p<0.01)$.

The transfer of lymph node and spleen cells did not prevent the destruction of pancreatic islets obtained from third party LEW.1A donors when transplanted into diabetic $\mathrm{BB} / \mathrm{OK}$ rats. The mean survival time in such animals amounted to $14.2 \pm 2.6$ days $(n=6)$ which is identical to untreated $\mathrm{BB} / \mathrm{OK}$ rats grafted with allogeneic islets $(14.4 \pm 1.6, n=10)$.

\section{Discussion}

There is increasing evidence that insulin-dependent diabetes mellitus in humans and certain animal models (BB rat, NOD mouse) is autoimmune in nature [12,13]. A cell-mediated autoimmune pancreatic Beta-cell destruction is discussed, because firstly, the disease can be transferred by lymphocytes [14-16], and secondly, thymectomy $[17,18]$, immunosuppression and immunomodulation prevent onset of disease [19-22]. The islet destruction process leading to hyperglycaemia has a long period before the onset of disease, in which phases of active destruction probably alternate with phases of a suppressed immune attack. Prior to diabetes onset a reduction of pancreatic Beta-cell volume and the appearence of insulitis was observed in the animals [2]. This was also observed in those animals which never developed diabetes [2,23], supporting the hypothesis of a spontaneous cessation of autoaggression in these animals. The described suppression of autoimmune pancreatic Beta-cell destruction by lymphocytes obtained from long-term normoglycaemic $\mathrm{BB} / \mathrm{OK}$ rats in which an immune attack had occurred in different 

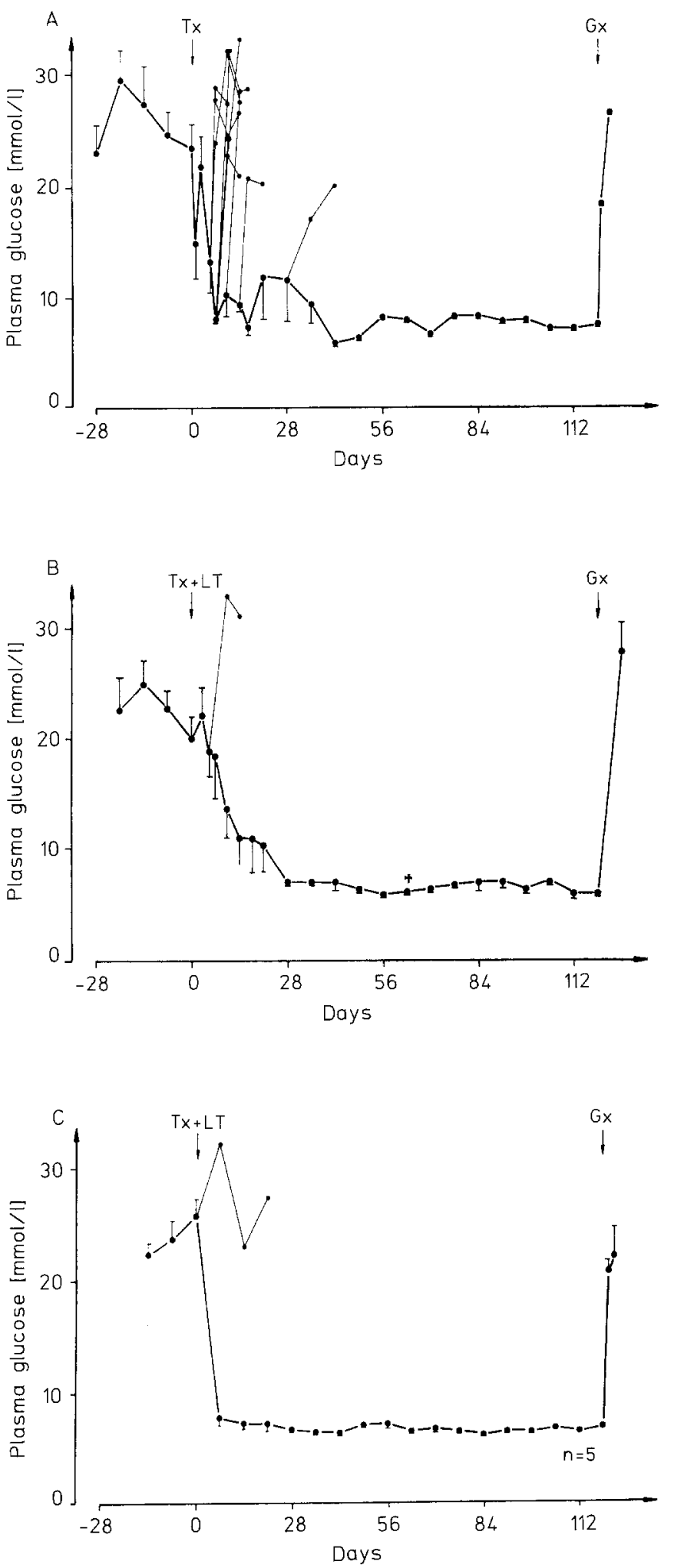

Fig. 1A-C. Plasma glucose of autoimmune diabetic BB/OK rats after syngeneic islet transplantation with and without transfusion of lymphocytes obtained from long-term normoglycaemic $\mathrm{BB} / \mathrm{OK}$ rats. A Islet transplantation without treatment of recipients (control); $n=12$. B Islet transplantation in combination with a transfusion of lymphocytes prepared from cervical lymph nodes and spleen; $n=10$. C Islet transplantation in combination with a transfusion of lymphocytes prepared from peripheral blood; $n=6 . \mathrm{T}_{\mathrm{x}}=$ Islet transplantation; $\mathrm{LT}=$ Lymphocyte transfer; $\mathrm{G}_{\mathrm{x}}=$ Graft removal; $\uparrow$ One animal died under anaesthesia experimental series suggests that a cell-mediated mechanism was responsible for the maintenance of normoglycaemia in the lymphocyte donors. Neither the lymphocyte number nor the cell composition of the lymphocytes transferred (data not shown) allows any conclusion regarding the cell population(s) involved. It seemed likely that $\mathrm{T}$ lymphocyte subpopulations were responsible for the observed effect [15].

In contrast to Rossini et al. [15, 24] and Logothetopoulos et al. [25] but in agreement with Burstein et al. [26] we prevented diabetes development by a single transfusion of lymphocytes. The cited authors $[15,25,26]$ used lymphocytes obtained from immunologically normal rat strains (diabetes-resistant, $\mathrm{RT}^{+}$) to arrest the autoimmune Beta-cell destruction, whereas in our study long-term normoglycaemic animals (in which insulitis had occurred) of a diabetes-prone BB rat strain served as lymphocyte donors.

Greiner et al. [27] observed diabetes development in $\mathrm{BB}$ rats only in the absence of a special lymphocyte population $\left(\mathrm{RT}^{+}{ }^{+}\right.$cells). The successful transfer of lymphocyte containing $\mathrm{RT}^{+}{ }^{+}$cells into $\mathrm{RT}^{-}{ }^{-}$diabetes-prone $\mathrm{BB}$ rats and the detection of the missing cell population following the transfer suggested that the prevention of diabetes may be mediated by RT $6^{+}$lymphocytes [26]. Our results, however, do not confirm a crucial role of $\mathrm{RT}^{+}{ }^{+} \mathrm{T}-\mathrm{lym}$ phocytes in preventing diabetes. On the contrary, our experiments clearly demonstrated the efficacy of an RT6 ${ }^{-}$lymphocyte population, because both the lymphocyte donors and recipients belong to the $\mathrm{BB} / \mathrm{OK}$ rat strain which is negative for RT6 T cells [28]. The third party transplantation demonstrated as expected, that the cell-mediated mechanism found in long-term normoglycaemic $\mathrm{BB} / \mathrm{OK}$ rats prevented autoimmune destruction of pancreatic Beta cells but not the allogeneic rejection.

In summary, the mechanism responsible for maintaining normoglycaemia in long-term normoglycaemic $\mathrm{BB} / \mathrm{OK}$ rats is cell-mediated, and can probably be maintained for life, indicating a possible role of memory cells. Furthermore, this property can be transferred to prevent autoimmune destruction of pancreatic Beta cells.

Acknowledgements. This study was part of the research project HFR 29 "Organtransplantation und Gewebekonservierung" of the Ministry of Health of the former GDR. The authors would like to thank Ms. Ch. Kauert, Ms. K. Gumm, Ms. H.Ohlrich, Ms. G.Strauch, Ms. M.Henkel, Ms. M.Behm and Ms. S.Kiowski for technical assistance and Ms. P. Schultz for typing the manuscript.

\section{References}

1. Naji A, Silvers WK, Barker CF (1985) Cell-mediated immunity in type I (insulin-dependent) diabetes of man and the BB rat. In: Cruse JM, Lewis RE (eds) Concepts immunopathol, Vol 2. Karger, Basel, pp 32-46

2. Lucke S, Diamantstein T, Hahn HJ (1989) Different lymphocyte subset distribution within "insulitis" islets of normoglycaemic and prediabetic BB/OK rats of similar age. Exp Clin Endocrinol 94: $57-63$

3. Weringer EJ, Like AA (1985) Immune attack on pancreatic islet transplants in the spontaneously diabetic Bio Breeding/Worcester $(\mathrm{BB} / \mathrm{W})$ rat is not MHC restricted. J Immunol 134: 2283-2286 
4. Weringer EJ, Like AA (1986) Diabetes mellitus in the BB/W rat: Insulitis in pancreatic islet grafts after transplantation into diabetic recipients. Am J Pathol 125: 107-112

5. Naji A, Silvers WK, Bellgrau D, Anderson AO, Plotkin S, Barker CF (1981) Prevention of diabetes in rats by bone marrow transplantation. Ann Surg 194: 328-338

6. Naji A, Bellgrau D, Anderson A, Silvers WK, Barker CF (1982) Transplantation of islets and bone marrow cells to animals with immune insulitis. Diabetes 31 [Suppl 4]: 84-89

7. Klöting I, Reiher K (1985) Einige Aspekte zur Haltung und Reproduktion spontandiabetischer BB Ratten. Z Versuchstierk 27: 5-11

8. Kuttler B, Volk HD, Kauert Ch, Diamantstein T, Hahn HJ (1989) Phenotyping of lymphocytes following transplantation of allogeneic rat pancreatic islets into streptozotocin-diabetic recipients. Exp Clin Endocrino 194: 64-69

9. Hehmke B, Kohnert KD, Odselius P (1986) The use of a new dextran gradient for rapid isolation of functionally intact neonatal pancreatic islets. Diabetes Res 3:13-16

10. Hahn HJ (1978) Die isolierte Langerhanssche Insel, ein Modell zur Untersuchung der Insulinsekretion in vitro. Endokrinologie 71: 308-324

11. Ziegler B, Hahn HJ, Ziegler M (1985) Insulin recovery in pancreas and host organs of islet grafts. Exp Clin Endocrinol 85 : $53-60$

12. Cahill GF Jr, McDevitt HO (1981) Insulin-dependent diabetes mellitus: the initial lesion. N Engl J Med 304: 1454-1465

13. Rossini AA, Mordes JP, Like AA (1985) Immunology of insulindependent diabetes mellitus. Ann Rev Immunol 3: 291-322

14. Like AA, Weringer EJ, Holdash A, McGill P, Atkinson D, Rossini AA (1985) Adoptive transfer of autoimmune diabetes mellitus in Biobreeding/Worcester (BB/W) inbred and hybrid rats. J Immunol 134: 1583-1585

15. Rossini AA, Faustman D, Woda BA, Like AA, Szymanski J, Mordes JP (1984) Lymphocyte transfusions prevent diabetes in the Bio-Breeding Worcester rat. J Clin Invest 74: 39-46

16. Wicker LS, Miller BJ, Mullen Y (1986) Transfer of autoimmune diabetes mellitus with splenocytes from nonobese diabetic (NOD) mice. Diabetes 35:855-860

17. Like AA, Kislauskis E, Williams RM, Rossini AA (1982) Neonatal thymectomy prevents spontaneous diabetes mellitus in the $\mathrm{BB} / \mathrm{W}$ rat. Science $216:$ 644-646

18. Ogawa M, Maruyama T, Hasegawa T, Kanaya T, Kobayashi F, Tochino Y, Uda H (1985) The inhibitory effect of neonatal thymectomy on the incidence of insulitis in nonobese-diabetic (NOD) mice. Biomed Res 6: 103-105
19. Laupacis A, Stiller CR, Gardell C, Keown P, Dupre J, Wallace AC, Thibert $\mathbf{P}$ (1983) Cyclosporin prevents diabetes in BB Wistar rats. Lancet I: 10-12

20. Mori Y, Suko M, Okudeira H, Matsuba J, Tsuruoka A, Sasaki A, Yokoyama $H$, Tanase T, Shida T, Nishimura M, Terada E, Ikeda Y (1986) Preventive effects of cyclosporin on diabetes in NOD mice. Diabetologia 29:244-247

21. Hahn HJ, Lucke S, Klöting I, Volk HD, v Baehr R, Diamantstein T (1987) Curing BB rats of freshly manifested diabetes by short-term treatment with a combination of monoclonal anti-interleukin 2 receptor antibody and a subtherapeutic dose of cyclosporine A. Eur J Immunol 17: 1075-1078

22. Like AA, Biron CA, Weringer EJ, Byman K, Sroczynski E, Guberski DL (1986) Prevention of diabetes in Bio-Breeding/Worcester rats with monocional antibodies that recognize T lymphocytes or natural killer cells. J Exp Med 164: 1145-1159

23. Lee KU, Amano K, Yoon JW (1988) Evidence for initial involvement of macrophage in development of insulitis in NOD mice. Diabetes 37: 989-991

24. Rossini AA, Mordes JP, Pelletier AM, Like AA (1983) Transfusions of whole blood prevent spontaneous diabetes in the BB/W rat. Science 219:975-977

25. Logothetopoulos J, Shimak K, Baily D (1988) Prevention of spontaneous but not adoptively transferred diabetes by injection of neonatal $\mathrm{BB} /$ hooded hybrid rats with splenocytes or Concanavalin A blasts from diabetes-free strains. Diabetes 37: 1009-1014

26. Burstein D, Mordes JP, Greiner DL, Stein D, Nakamura N, Handier ES, Rossini AA (1989) Prevention of diabetes in $\mathrm{BB} /$ Wor rats by single transfusion of spleen cells. Parameters that affect degree of protection. Diabetes 38:24-30

27. Greiner DL, Handler ES, Nakano K, Mordes JP, Rossini AA (1986) Absence of RT-6 T cell subset in diabetes-prone BB/W rats. J Immunol 136: 148-151

28. Klöting I, Vogt L, Günther E, Wurst W, Hedrich HJ, Reetz JC (1989) Availability of newly established congenic rat strains LEW.1BB and BB.1A. RNL 21: 22-23

Received: 8 February 1990

and in revised form: 15 August 1990

Dr. B. Kuttler

Institute of Diabetes "G. Katsch"

O-2201 Karlsburg

FRG 